\title{
Entre tu i jo, nosaltres
}

Joan Calsina

En el principi hi ha el final, però com podem creure-ho si és el principi de l'amor?

Pere Rovira

Em dius que vols sentir la meva veu, una vegada més, en les gastades ratlles que no saben dir-nos si en tot inici hi ha un final. Estimar: desaprendre a ser tu i jo per començar a ser, tan sols, nosaltres. Ja ho has vist?

Aquest dia rere dia on lentament cremem els nostres somnis és tot el guany que ens ofereix el temps. Per què esperar-ne més? Deixem passar les hores sota l'ombra amable d'aquests àlbers; tornem al nostre món de sempre.

I quan el vent s'emporti el darrer hivern, quan el matí blavós s'endugui les nits d'ara, no perdis l'esperança:

un fil de vida ens unirà, encara, més enllà de nosaltres. Perquè, si en tot principi hi ha un final, no és tot final el bell principi de l'amor? 